\title{
EXCEPTIONAL PRESERVATION OF BASAL YORKTOWN FORMATION (PLIOCENE) MOLLUSCAN FAUNAS, JAMES RIVER, VIRGINIA
}

CAMPBELL, Matthew R., Department of Geology, CB 3315, UNC-CH, Chapel Hill, NC 27599-3315, U.S.A.

The Yorktown Formation of Early and Middle Pliocene age (4.4 to 3.2 Ma) crops out throughout the Atlantic Coastal Plain of Virginia and North Carolina. The diverse and well-preserved faunas of the Zone 2 beds of Mansfield are laterally extensive, lithologically complex, and better studied than the Sunken Meadow Member of Ward or Zone 1 of Mansfield.

Zone 1 is exposed at Kingsmill and Carter's Grove, James City County, Virginia, on the north bank of the James River. Zone 2 beds, with a basal pavement of disarticulated large bivalves, disconformably overlie truncated Zone 1 beds. Placopecten clintonius and Chesapecten jeffersonius are common Zone 1 index species. Zone 1 beds include a lower fine sand and an upper very shelly sand. There is a gradual transition to upper beds, which contain similar fine quartzose sand, but more whole and fragmented shell. In the upper Zone 1 beds, abundant single valves of $\underline{\underline{C}}$. jeffersonius lie current-oriented and convex-up, paving sand waves. The estimated number of encrusting species and endolithic species increases upwards through the section. The documented Zone 1 molluscan fauna was increased by 103 species to a total of 208 species, including about 20 undescribed species. Lithologic and paleontologic changes in the Zone 1 section reflect a regressive, shallowing upwards sequence during a relative sea level fall in the Early Pliocene around 4.2 mybp.

At Kingsmill, Leptopecten leonensis is found in a lens of densely packed shell and comminuted shell carbonate. The lens is preserved in the trough of a sand wave in Zone 1, and is truncated by a regional unconformity marking the base of the Rushmere Member of Ward (lower Zone 2). Both the lens and the overlying unconformity contain much shell reworked from Zone 1 sources. Other taxa restricted to the lens include Chione cortinaria and Chesapecten madisonius carolinensis (10-15 rib variety). The calcitic species of the lens assemblage are known from several leached, calcarenite deposits of disputed age, including the Tamiami Limestone of southern Florida, the lower Goose Creek Limestone of North and South Carolina, the basal Zone 2 Yorktown beds of the Aurora, North Carolina phosphate pits, and the Leptopecten beds on and near the Piankitank River in Virginia. The Kingsmill lens and equivalent beds at Carter's Grove and Cobham Wharf preserve aragonitic shell and micromolluscs, providing an opportunity to better document this assemblage. As a result, the Kingsmill section provides precise stratigraphic control for this elusive unit, confirming a postSunken Meadow, pre-Rushmere placement for these beds. 